\title{
Corrosion Inhibition of Pipeline Steel X-70 in Sour Brine by an Imidazoline Derivative under Flow Assisted Conditions
}

\author{
M. Díaz-Cruz ${ }^{1, *}$, M. A. Domínguez-Aguilar ${ }^{2}$, A. Cervantes-Tobón ${ }^{1}$, B. Castro-Domínguez ${ }^{3}$, \\ F. Jiménez-Cruz ${ }^{2}$, M.T. Fuentes-Romero ${ }^{4}$. \\ ${ }^{1}$ Instituto Politécnico Nacional, Departamento de Ingeniería Metalúrgica, IPN-ESIQIE, U.P. Adolfo \\ López Mateos, Zacatenco, C.P. 07738, México, D.F., México. \\ ${ }^{2}$ Instituto Mexicano del Petróleo, Laboratorio de Producción de Hidrocarburos y Control de la \\ Corrosión, Eje Central Norte Lázaro Cárdenas 152, Col. San Bartolo Atepehuacan, C.P. 07730, \\ México D.F., México. \\ ${ }^{3}$ Worcester Polytechnic Institute, Center for Inorganic Membrane Studies, Department of Chemical \\ Engineering, Worcester Massachusetts, WA 01609, US. \\ ${ }^{4}$ Universidad Tecnológica Fidel Velázquez, Departamento de Nanotecnología, Av. Emiliano Zapata \\ S/N, El Tráfico, 54400 Villa Nicolás Romero, Atizapán, Edo. De México, México \\ "E-mail: mdiazc@ipn.mx, neladiaz1346@gmail.com
}

doi: $10.20964 / 2017.08 .45$

Received: 25 April 2016 / Accepted: 10 January 2017 / Published: 12 July 2017

The corrosion behavior of a pipeline steel API 5L X-70 was tested under flow assisted conditions in a sour brine solution containing kerosene in the presence of an imidazoline derivative. Inhibitor film provided efficiencies in the range of $70-99 \%$ at $200 \mathrm{ppm}$ with initial corrosion rates in the range of 125-134 mpy (3.2-3.4 mm/y). In the absence of inhibitor, chemical species of cubic maghemite $\left(\mathrm{Fe}_{2} \mathrm{O}_{3}\right)$ predominated with an apparent decrease in orthorhombic marcasite $\left(\mathrm{FeS}_{2}\right)$ on the steel surface when angle was increased from $30^{\circ}$ to $90^{\circ}$. In the presence of inhibitor, maghemite $\left(\mathrm{Fe}_{2} \mathrm{O}_{3}\right)$ and marcasite $\left(\mathrm{FeS}_{2}\right)$ prevailed as a mixture of oxides and sulfides at the impingement angles. Mackinawite appeared with and without the presence of corrosion inhibitor at every angle tested. As flow rate and angle are increased, inhibitor efficiency decreased due to partial film formation. Imidazoline derivative is efficient albeit a periodic replenishment is required after a 3-4 hour period. DFT molecular simulation of imidazoline derivative emphasized nitrogen polarity and capability of interacting with another molecular species.

Keywords: Flow assisted corrosion, sour brine, jet impingement, API X-70.

FULL TEXT 
(C) 2017 The Authors. Published by ESG (www.electrochemsci.org). This article is an open access article distributed under the terms and conditions of the Creative Commons Attribution license (http://creativecommons.org/licenses/by/4.0/). 